\title{
Pengaruh Pemberian Pendidikan Kesehatan Terhadap Kecemasan Ibu Hamil pada Masa Pandemi Covid-19
}

\author{
Inggit Primadevi $i^{*}$, Retno Yuniarti ${ }^{2}$ \\ ${ }^{1}$ Universitas Aisyah Pringsewu \\ ${ }^{2}$ Puskesmas Segalamider Kota Bandar Lampung
}

\section{ARTICLE INFO}

\section{Article history:}

Received 21 April 2021

Accepted 21 August 2021

Published 25 October 2021

\section{Keyword:}

Health Education

Pregnant Women

Anxiety

Covid-19

Pandemic

\section{A B S T R A C T}

Psychological changes in pregnant women are divided into several trimester phases according to fetal development. During the Coronavirus Disease 2019 (covid-19) pandemic, the anxiety level of pregnant women is increasing. The research objective was to know the effect of health education on pregnant women's anxiety during the COVID-19 pandemic. This type of research was pre-experimental with a one-group pretest and posttest design. The population is all pregnant women who are at the Public Health Center of Segalamider, Bandar Lampung City with totalling 36 people, the sampling technique used was total sampling. Univariate analysis used range values and bivariate analysis used the Wilcoxon test. The results of the research show the average level of anxiety of pregnant women before health education was 10.5 , the average level of anxiety of pregnant women after health education was 6.6 and there was an effect of providing health education on the anxiety of pregnant women during the COVID-19 pandemic with p-value $=0.000$. Suggestions for mothers are expected to be able to consult with midwives regarding physical and psychological health conditions while still implementing health protocols so that they can prevent anxiety during pregnancy during the covid-19 pandemic.

This open access article is under the CC-BY-SA license.

Kata kunci:

Pendidikan Kesehatan

Kecemasan

Ibu Hamil

Pandemic

Covid-19

\section{*) corresponding author}

Universitas Aisyah Pringsewu

Jl. A. Yani No. 1A Tambahrejo

Kec. Gadingrejo Kabupaten Pringsewu

Lampung 35372

Email: inggitprimadevi16@gmail.com

DOI: $10.47679 /$ makein.202141

\section{A B S T R A K}

Perubahan psikologis pada wanita hamil terbagi kedalam beberapa fase trimester sesuai dengan perkembangan janin. Dimasa pandemi Coronavirus Disease 2019 (covid-19) tingkat kecemasan ibu hamil mengalami peningkatan. Tujuan penelitian ini Diketahui pengaruh pendidikan kesehatan terhadap kecemasan ibu hamil pada masa pandemicovid-19. Jenis penelitian ini pra eksperimen dengan rancangan one group pretest dan posttest. Populasinya adalah seluruh ibu hamil yang ada di UPT Puskesmas Segalamider Kota Bandar Lampung yang berjumlah 36 orang, dengan sampel total populasi, teknik sampling yang digunakan Total Sampling. Analisis univariat nilai range dan analisis bivariate uji Wilcoxon. Hasil penelitian menunjukkan rata-rata tingkat kecemasan ibu hamil sebelum dilakukan pendidikan kesehatan sebesar 10,5, rata-rata tingkat kecemasan ibu hamil setelah dilakukan pendidikan kesehatan sebesar 6,6 dan ada pengaruh pemberian pendidikan kesehatan terhadap kecemasan ibu hamil pada masa pandemik covid-19 dengan $p$ value $=0,000$. Saran bagi Ibu diharapkan dapat melakukan konsultasi kepada bidan mengenai keadaan kesehatan fisik dan psikis dengan tetap menerapkan protokol kesehatan sehingga dapat mencegah timbulnya kecemasan selama kehamilan di masa pandemic covid-19. 


\section{PENDAHULUAN}

Dimasa pandemi Coronavirus Disease 2019 (covid-19) tingkat kecemasan ibu hamil meningkat 50,7\% dan berdasarkan analisis yang dilakukan oleh Corbett et all mengenai health anxiety and behavioural changes of pregnant women during the covid-19 pandemic tahun 2020 menyatakan bahwa ibu hamil trimester kedua dan ketiga mengalami kekhawatiran tentang kehamilan sejak terjadinya pandemic covid-19 lebih dari 50,7\% dengan perbandinga 66,7\% khawatir terhadap kehamilannya dan kekhawatiran terhadap perawatan bayi sebesar $34,3 \%$. Pemeriksaan kehamilan atau Antenatal care adalah pemeriksaan kehamilan yang dilakukan untuk mengoptimalkan kesehatan mental dan fisik dari ibu hamil tetapi di masa pandemi covid-19 memberikan berbagai kekhawatiran, apalagi jika harus rutin datang ke rumah sakit. Keadaan atau kondisi saat ini sama seperti kondisi sebelum pandemi covid 19 terjadi, hanya saja dengan adanya pandemi covid-19 harus lebih memperhatikan protokol kesehatan (Mohammad, 2020).

Pandemi covid-19 juga menyebabkan banyak pembatasan hampir ke semua layanan rutin, baik secara akses maupun kualitas, termasuk pembatasan dalam pelayanan kesehatan maternal dan neonatal, seperti adanya pengurangan frekuensi pemeriksaan kehamilan dan penundaan kelas ibu hamil (Direktorat Kesehatan Keluarga, 2020).

Kondisi-kondisi tersebut dapat menjadikan permasalahan secara psikologis bagi ibu hamil dan ibu nifas, yang dapat menimbulkan kecemasan. Perubahan psikologis menjadi salah satu faktor predisposisi dari terhambatnya pertumbuhan dan perkembangan janin sedangkan pada efek jangka panjang keadaan ini akan mempengaruhi perawatan kesehatan baik ibu maupun anak yang dilahirkan sehingga perlu adanya strategi dalam memberikan pengetahuan mengenai tindakan dan pencegahan sedini mungkin (Cameron et all, 2020).

Salah satu bentuk tindakan dan dukungan dari seorang bidan adalah dengan memberikan pendidikan kesehatan atau yang biasa disebut dengan promosi kesehatan yang merupakan upaya yang dilakukan untuk meningkatkan kemampuan masyarakat baik pengetahuan, sikap maupun perilaku kesehatan melalui proses pembelajaran diri, oleh, untuk dan bersama masyarakat (Notoatmodjo, 2018).

Penelitian yang telah dilakukan oleh Ernawati dan Hernowo (2016) di Rumah Sakit Militer Kota Malang menunjukkan bahwa pendidikan kesehatan berperan terhadap tingkat kecemasan ibu primigravida dan multigravida untuk menghindari atau mengurangi stress psikologis ibu atau meningkatkan rasa sejahtera bagi ibu yang akan dapat mendorong proses persalinan secara fisiologis. Kecemasan mempunyai efek negatif bagi ibu hamil (khususnya hamil pertama), karena dengan adanya kecemasan maka akan meningkatkan kadar ketokolamin dalam tubuh ibu yang dapat menyebabkan penurunan aliran darah ke rahim dan penurunan kontraksi rahim, sehingga aliran darah ke plasenta juga menurun dan menyebabkan pasokan oksigen ke janin menurun. Masalah ini akan berdampak bagi keselamatan ibu dan janinnya seperti kematian janin, kelahiran prematur dan perdarahan saat persalinan.

Tingkat kecemasan yang terjadi pada masing-masing ibu hamil pasti berbeda-beda tetapi menurut Zamriati et al., (2013), salah satu faktor yang mempengaruhi kecemasan adalah rendahnya pendidikan yang akan menyebabkan seseorang mengalami stress dan kecemasan, hal tersebut terjadi disebabkan karena kurangnya informasi dan pengetahuan pada ibu hamil mengenai kesehatan dan kehamilannya. Kecemasan masa pandemic covid-19 yang dialami oleh sebagaian besar masyarakat pada awalnya tidak diketahui secara pasti terutama bagaimana cara memutus mata rantai penularan virus tersebut demikian juga pada wanita hamil yang rentan menghadapi kecemasan dengan adanya janin yang harus dirawat didalam kandungan (Suratj B, 2020).

Hasil presurvei dengan cara wawancara pada petugas Puskesmas Segala Mider bahwa pada kurun waktu 3 bulan terakhir sering ditemukan ibu hamil yang merasa takut dan khawatir terhadap kehamilannya terutama pada kehamilan pertama atau primigravida selama masa pandemic covid-19 sehingga pada penelitian ini peneliti mencoba melakukan wawancara sederhana pada beberapa ibu hamil di Puskesmas Segala Mider dan menghasilkan, dari tujuh orang ibu hamil primigravida dan multigravida yang diwawancarai, mereka merasa takut bayinya tidak sehat karena takut tertular dari orang-orang yang mereka jumpai dan mereka mengatakan takut bertemu dengan orang-orang sehingga merasa cemas dan tidak tahu cara menghilangkan rasa cemas tersebut, mereka hanya berharap rasa takut tersebut akan hilang dengan sendirinya.

Pendidikan kesehatan dalam bidang kesehatan dikenal dengan promosi kesehatan, yaitu upaya untuk meningkatkan kemampuan masyarakat melalui proses pembelajaran diri, oleh untuk dan bersama masyarakat (Notoatmodjo, 2018). Pendidikan kesehatan adalah suatu kegiatan atau usaha menyampaikan pesan kesehatan kepada masyarakat, kelompok atau individu, dengan harapan masyarakat, kelompok atau individu dapat memperoleh pengetahuan tentang kesehatan yang lebih baik sehingga pada akhirnya akan berpengaruh pada perubahan perilaku (Notoatmodjo, 2018).

Suratj B (2020) mengemukanan bahwa rekomendasi dari para ahli dalam menentukan pedoman mengelola covid-19 selama kehamilan dan persalinan pada masa pandemi covid19 belum pasti karena masih bervariatif secara teori dan belum memiliki atau masih kurangnya bukti yang kuat dan kajian dampak terhadap ibu hamil belum dapat dievalusi dengan baik, tetapi secara psikologis wanita hamil rentan akan mengalami kecemasan dengan adanya janin yang harus dirawat didalam kandungan dan pada masa kehamilan ini secara fisiologis terjadi perubahan emosional dari ibu hamil.

Perubahan emosional yang terjadi adalah perasaan gembira bercampur takut.Perubahan ini membuat ibu hamil merasakan kecemasan, khawatir, gelisah dan tidak tenteram.Hampir seluruh ibu hamil mengalami kecemasan yang membedakan adalah tingkat kecemasannya.Pada masa kehamilan peran serta bidan atau tenaga kesehatan diperlukan dalam memberikan pendidikan kesehatan dan edukasi bagi ibu hamil sehingga dapat memberikan rasa nyaman dalam menghadapi masa kehamilan.Pendidikan kesehatan bertujuan untuk mengatasi masalah kecemasan psikis selama masa kehamilan (Dale, 2019).

Metode penyuluhan mempengaruhi tingkat kecemasan pada ibu hamil dimana setelah dilakukan kegiatan pemberian pendidikan kesehatan dengan menggunakan teknik pennyuluhan yang diikuti dengan adanya demonstrasi, redemonstrasi, dan diskusi interpersonal, terjadi peningkatan pemahaman dan menurunnya kecemasan ibu hamil. Kecemasan tidak akan terjadi apabila pengetahuan seseorang tersebut cukup baik dan peningkatan pemahaman peserta dikarenakan sebagai hasil dari kegiatan penyuluhan (Aritonang, 2020). Berdasarkan fenomena di atas peneliti tertarik melakukan penelitian 
dengan judul "Pengaruh Pemberian pendidikan kesehatan Terhadap Kecemasan Ibu Hamil Pada Masa Pandemi Covid$19 "$.

\section{METODE}

Jenis Penelitian yang digunakan dalam penelitian ini yaitu pra eksperimen yang bertujuan untuk menguji hipotesis sebab akibat dengan melakukan intervensi (Notoatmodjo, 2010). Penelitian ini dilaksanakan pada Tanggal 15 Maret sampai 15 April 2021 bertempat di UPT Puskesmas Segalamider Kota Bandar Lampung. Rancangan penelitian ini menggunakan pendekatan one group pretest dan post test yaitu terdapat pretest sebelum diberi perlakuan dan post test setelah diberi perlakuan, kemudian membandingkan keadaan sebelum dan setelah diberi perlakuan (Notoatmodjo, 2010). Desain yang digunakan menggunakan skema:

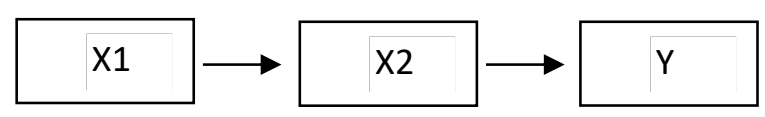

$\mathrm{X} 1$ = skor kecemasan ibu hamil sebelum intervensi

$\mathrm{X} 2$ = skor kecemasan ibu hamil setelah intervensi

$\mathrm{Y}=$ pendidikan kesehatan kehamilan (intervensi)

Pada penelitian ini yang menjadi populasi adalah seluruh ibu hamil yang ada di UPT Puskesmas Segalamider Kota Bandar Lampung Tahun 2021 dengan jumlah ibu hamil sebanyak 36 orang. Sampel dalam penelitian ini yakni seluruh ibu hamil yang ada di UPT Puskesmas Segalamider Kota Bandar Lampung pada saat penelitian berlangsung yang sesuai dengan kriteria inklusi sebanyak 36 orang. Teknik yang digunakan dalam penelitian ini adalah Total sampling, dimana seluruh populasi menjadi sampel penelitian (Notoatmodjo, 2010). Kriteria inklusi dalam penelitian ini adalah Ibu hamil primigravida dan multigravida serta bersedia menjadi responden dan tidak sedang dirawat di Rumah Sakit. Variabel independen dalam penelitian ini adalah pendidikan kesehatan dan variabel dependen kecemasan ibu hamil.

Pengumpulan data dilakukan penulis dengan cara bekerjasama dengan Bidan Poskeskel dan Kader untuk mengumpulkan ibu di masing-masing Poskeskel wilayah UPT Puskesmas Segalamider. Setelah berkumpul peneliti menjelaskan tujuan penelitian dan membagikan lebar informed consent, jika setuju menjadi responden ibu akan tanda tangan pada lembar tersebut. Peneliti kemudian melakukan wawancara yang berkaitan dengan kecemasan. Peneliti membuat jadwal untuk pertemuan dan pendidikan kesehatan, setelah jadwal disepakati maka peneliti bisamemberikan pendidikan kesehatan pada ibu hamil melalui presentasi atau ceramah menggunakan media power point yang kemudian diikuti dengan diskusi dan tanya jawab mengenai kehamilan dan proses persalinan pada masa pandemi covid-19. Kemudian peneliti meminta ibu hamil untuk datang kembali pada minggu selanjutnya dan peneliti menilai kembali tingkat kecemasan ibu hamil menggunakan checklist yang sama.
Pengumpulan data dilakukan dengan cara, wawancara yang dilakukan dengan menggunakan 14 kategori gejala kecemasan. Pengumpulan data dilakukan dengan cara ibu hamil menjawab setiap pertanyaan yang diberikan oleh peneliti dan peneliti melakukan checklist terhadap hasil wawancara tersebut. Setiap pertanyaan memiliki beberapa gejala yang menjadi acuan dalam menentukan skor, jika ibu hamil tidak merasakan gejala sama sekali diberi nilai 0 (tidak ada kecemasan), jika ada satu gejala diberi nilai 1 (kecemasan ringan), jika mengalami separuh dari gejala yang ada diberi nilai 2 (kecemasan sedang) dan jika lebih dari separuh gejala yang ada diberi nilai 3 (kecemasan berat) sedangkan jika memiliki seluruh gejala maka diberi nilai 4 (kecemasan berat sekali).

Analisis Penelitian yang dilakukan adalah Analisis Univariat yaitu dimaksudkan untuk mengetahui distribusi frekuensi dari sub variabel yang diamati sehingga dapat mengetahui gambaran dari variabel yang diteliti (Notoatmodjo, 2010), dan Analisis bivariat Pada penelitian ini hasil sebaran selisih yang dihitung tidak normal sehingga analisis bivariate dalam penelitian ini menggunakan uji non parametric Wilcoxon Sign Test.

\section{HASIL DAN DISKUSI}

Tabel 1.

Distribusi Frekuensi Usia, Pendidikan dan Pekerjaan Ibu Hamil Pada Masa Pandemi Covid-19

\begin{tabular}{cll}
\hline Usia & Frekuensi & Persentase (\%) \\
\hline$<20$ tahun & 9 & 25,0 \\
20-35 tahun & 17 & 47,2 \\
$>35$ tahun & 1 & 27,8 \\
$\begin{array}{c}\text { Pendidikan } \\
\text { SD }\end{array}$ & 3 & \\
SMP & 11 & 8,3 \\
SMA & 17 & 40,6 \\
PT & 5 & 13,2 \\
Pekerjaan & & \\
IRT & 20 & 55,6 \\
Buruh & 5 & 13,9 \\
Swasta & 8 & 22,2 \\
Petani & 3 & 8,3 \\
Paritas & & 52,8 \\
Primigravida & 19 & 47,2 \\
Multigravida & 17 & 100,0 \\
\hline Jumlah & 36 & \\
\hline
\end{tabular}

Tabel 1 menunjukkan sebagian besar responden berusia 20-35 tahun sebanyak 17 orang (47,2\%), sebagian besar responden berpendidikan SMA sebanyak 17 orang $(47,2 \%)$, sebagian besar responden bekerja sebagai Ibu Rumah Tangga sebanyak 20 orang $(55,6 \%)$ dan sebagian responden dengan paritas primigravida sebanyak 19 orang $(52,8)$.

Grafik 1 terlihat bahwa dari 36 responden diperoleh nilai rerata (mean) kecemasan sebelum dilakukan pendidikan kesehatan sebesar 10,5 dengan standar deviasi 3,09. Grafik 2 terlihat bahwa dari 36 responden diperoleh nilai rerata (mean) kecemasan setelah dilakukan pendidikan kesehatan sebesar 6,6 dengan standar deviasi 2,55. 


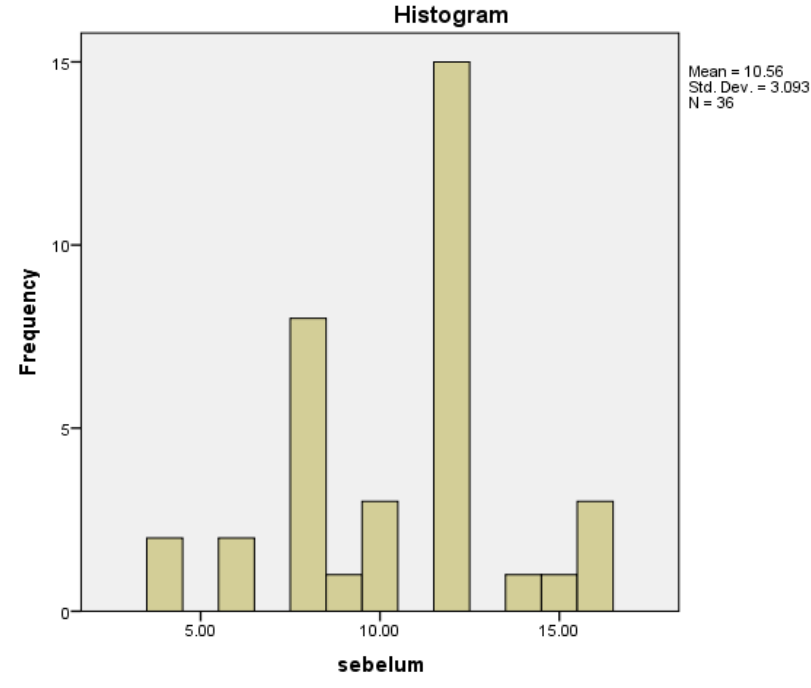

Grafik 1.

Rerata skor Kecemasan pada Ibu hamil Sebelum Intervensi

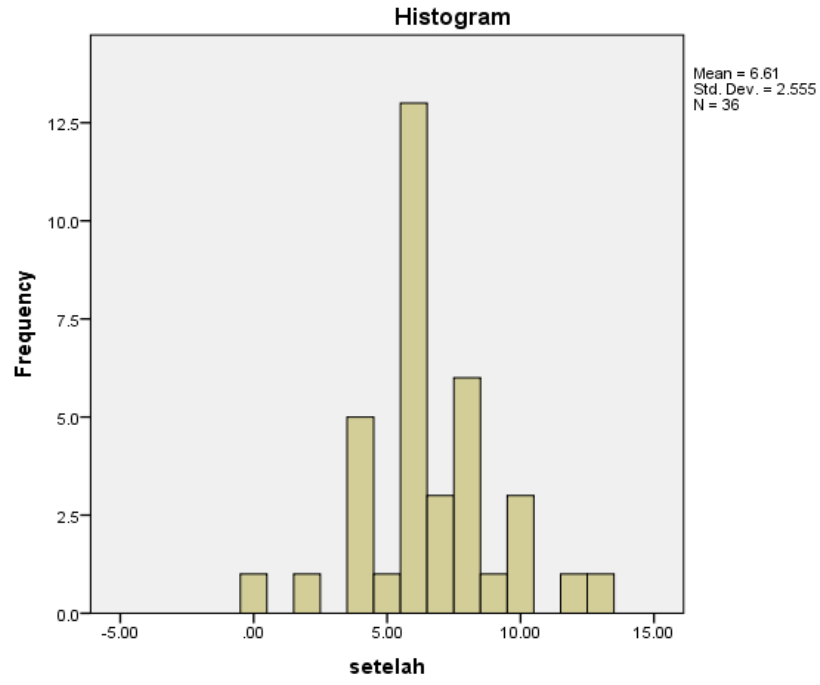

Grafik 2

Rerata skor Kecemasan pada Ibu hamil Setelah Intervensi

Tabel 2

Uji Normalitas Tingkat Kecemasan Ibu Hamil Sebelum dan Setelah Intervensi

\begin{tabular}{cllll}
\hline Variabel & Shapiro Wilk & $\begin{array}{c}\text { Standar } \\
\text { Error }\end{array}$ & 95\% CI & $\begin{array}{c}\text { Median } \\
\text { (Minimum- } \\
\text { Maksimun) }\end{array}$ \\
\hline Kecemasan sebelum dilakukan pendidikan kesehatan & 0,012 & 0,393 & $9,5-11,6$ & $12(4-16)$ \\
Kecemasan setelah dilakukan pendidikan kesehatan & 0,048 & 0,393 & $5,7-7,4$ & $6(0-13)$ \\
\hline
\end{tabular}

Tabel 2 menunjukkan bahwa hasil 95\% confidence interval tingkat kecemasan ibu hamil sebelum dilakukan pendidikan kesehatan yaitu 9,5-11,6 dengan hasil uji kenormalan data 0,012 sehingga hasil uji normalitas $<0,05$. Hasil tingkat kecemasan ibu hamil setelah dilakukan pendidikan kesehatan 95\% confidence interval yaitu 5,7-7,4 dengan hasil uji kenormalan data 0,048, dan selisih hasil uji normalitas $<0,05$ maka disimpulkan bahwa variabel tingkat kecemasan sebelum dan setelah dilakukan pendidikan kesehatan berdistribusi tidak normal.

Tabel 3

Pengaruh Pemberian Pendidikan Kesehatan Terhadap Kecemasan Ibu Hamil

\begin{tabular}{lcccc}
\hline Tingkat Kecemasan & N & Mean & $\begin{array}{c}\text { Median } \\
\text { (Minimum-Maksimun) }\end{array}$ & P Value \\
\hline Sebelum Intervensi & 36 & 10,5 & $\begin{array}{c}12 \\
(4-16)\end{array}$ & 0,000 \\
Setelah intervensi & 36 & 6,6 & 6 \\
$(0-13)$
\end{tabular}

Hasil analisis berdasarkan Tabel 3 dari 36 orang responden diperoleh hasil rata-rata tingkat kecemasan sebelum dilakukan pendidikan kesehatan adalah 10,5, dan tingkat kecemasan setelah dilakukan pendidikan kesehatan 6,6. Tingkat kecemasan terkecil sebelum dilakukan pendidikan kesehatan adalah 4 atau tidak cemasa dan tertinggi 16 atau cemas ringan sedangkan tingkat kecemasan setelah dilakukan pendidikan kesehatan terkecil adalah 0 dan tertinggi 13 atau tidak ada kecemasan. Nilai signifikansi diperoleh sebesar 0,000, oleh karena $p=0,000<0,05$ maka dapat dinyatakan terdapat pengaruh tingkat kecemasan pada ibu hamil antara sebelum dan setelah dilakukan pendidikan kesehatan.

\section{PEMBAHASAN HASIL PENELITIAN}

\section{Tingkat Kecemasan Sebelum Dilakukan Pendidikan Kesehatan}

Berdasarkan hasil penelitian ini tingkat kecemasan bervariasi dimulai dari 4 sampai dengan 16, dimana nilai 0 14 dinilai sebagai tidak ada kecemasan sedangkan nilai 1516 termasuk kedalam tingkat kecemasan ringan. Pada penelitian ini jika dilihat dari nilai rerata (mean) kecemasan ibu hamil sebelum dilakukan pendidikan kesehatan diperoleh nilai sebesar 10,5.

Menurut Suherni dalam Sutanto dan Fitriana (2019) perubahan psikologis masa kehamilan merupakan perubahan sikap dan perasaan tertentu selama kehamilan 
yang memerlukan adaptasi atau penyesuaian. Adapun bentuk perubahan psikologis pada masa kehamilan yaitu perubahan mood seperti sering menangis, lekas marah, dan sering sedih atau cepat sedih dan mudah berganti senang yang merupakan manifestasi dari emosi yang labil. Selain itu perubahan psikologis pada ibu hamil seperti perasaan gembira bercampur khawatir dan kecemasan menghadapi perubahan peran yang akan dijalani selama kehamilan.

Dalam penelitian ini hasil penelitian menunjukkan bahwa $52,8 \%$ atau sebagian ibu hamil untuk pertama kalinya atau primigravida memiliki tingkat kecemasan lebih tinggi, hal ini dimungkinkan karena ibu hamil mengalami reaksi kecemasan terhadap cerita yang diperolehnya dari teman atau wanita yang sudah terlebih dahulu mengalami kehamilan dan persalinan. Pada masa pandemik covid-19 ini kecemasan ibu hamil bukan hanya pada kehamilan dan persalinan semata tetapi juga kecemasan terhadap virus covid apakah akan memberikan dampak pada kehamilan dan persalinan sehingga akan muncul ketakutan-ketakutan pada ibu terutama yang baru pertama kali hamil.

Hasil penelitian ini sejalan dengan penelitian oleh Diki Retno Yuliani dan Fajaria Nur Aini (2020) tentang Kecemasan Ibu Hamil Pada Masa Pandemi Covid-19. Hasil penelitian menunjukan pada masa pandemi COVID-19, 75 \% ibu hamil di Kecamatan Baturraden mengalami kecemasan dari skala ringan, sedang sampai skala berat, dengan mayoritas tingkat kecemasan ibu hamil adalah kategori ringan-sedang

Dalam penelitian ini usia menjadi salah satu faktor internal yang mempengaruhi tingkat kecemasan ibu hamil. Semakin muda usia semakin sedikit pengalaman dan tingkat pengetahuannya tentang kehamilan dan persalinan yang didapat, sehingga dapat dikatakan bahwa usia muda lebih besar kemungkinannya untuk mengalami kecemasan. Dimana pada usia tersebut adalah masa antara remaja akhir dan dewasa muda atau awal yang belum banyak memiliki pengalaman dan pengetahuan tentang kehamilan maupun persalinan. Dalam penelitian ini sebagian atau $25 \%$ ibu hamil yang mengalami kecemasan berusia antara 20 sampai dengan 35 tahun. Dimasa pandemic covid-19 ini juga informasi yang diperoleh ibu masih kurang yang berkaitan dengan bagaimana cara penularan virus covid dan apakah berbahaya bagi kehamilan yang sedang dialami serta bagaimana persalinan yang akan dihadapi.

Pada ibu hamil yang belum pernah mendapatkan informasi baik tentang kehamilan maupun persalinan dimasa pandemic covid-19 dengan diberikannya pendidikan kesehatan akan dapat mengurangi stres psikologis sehingga ibu tidak merasakan kecemasan yang berlebihan seperti menurut Notoatmodjo (2018) pendidikan kesehatan adalah suatu kegiatan atau usaha menyampaikan pesan kesehatan kepada masyarakat, kelompok atau individu, dengan harapan masyarakat, kelompok atau individu dapat memperoleh pengetahuan tentang kesehatan yang lebih baik sehingga pada akhirnya akan berpengaruh pada perubahan perilaku.

Perubahan perilaku seseorang dimulai dari perubahan tingkat pengetahuan. Dari sini diharapkan suatu pola fikir dari ibu hamil agar menyikapi kehamilannya pada masa pandemic covid-19 dengan suatu konsep, bahwa kehamilannya merupakan suatu proses fisiologis wanita yang normal dengan terus menerapkan protokol kesehatan sehingga diharapkan dengan diberikannya pendidikan kesehatan akan mengurangi tingkat kecemasan ibu hamil.

Untuk itu diharapkan bidan dapat terus memberikan pendidikan kesehatan ataupun konseling kepada ibu hamil sehingga dapat mengantisipasi kecemasan yang terjadi pada ibu hamil. Serta memberikan informasi mengenai kehamilan dan persiapan persalinan pada masa pandemic covid-19 dan cara mengendalikan perubahan psikologi ibu hamil.

\section{Tingkat Kecemasan Setelah Dilakukan Pendidikan Kesehatan}

Berdasarkan hasil penelitian bahwa tingkat kecemasan pada ibu hamil bervariasi dimulai dari 0 sampai dengan 13 dengan nilai rerata (mean) kecemasan setelah dilakukan pendidikan kesehatan sebesar 6,6, dan dalam kategori tidak cemas. Sedangkan Ibu yang sebelumnya mengalami kecemasan ringan menurun menjadi tidak mengalami kecemasan.

Dale (2019) mengungkapkan bahwa cara mengatasi kesemasan pada masa kehamilan dapat dilakukan dengan 2 cara, yakni komunikasi dan konseling. Komunikasi terapeutik yang mengarah pada bentuk komunikasi interpersonal dalam mengatasi gangguan psikologis bertujuan untuk membantu pasien, memperjelas dan mengurangi beban psikologis, perasaan dan pikiran yang dialami ibu hamil serta mampu mengenali identitas diri dengan baik sehingga ibu hamil mampu beradaptasi dengan kondisi psikologisnya yang baru dan mampu memulai kehidupan dengan baik sedangkan Bimbingan/konseling dbertujuan untuk memecahkan masalah, pemenuhan kebutuhan emosi, perubahan tingkah laku atau sikap dari hasil pengumpulan dan pemberian informasi yang diberikan.

Hasil penelitian ini sejalan dengan penelitian oleh Heni Purwaningsih (2020) tentang Analisis Masalah Psikologis pada Ibu Hamil Selama Masa Pandemi Covid-19. Hasil penelitian menunjukkan sebagian besar wanita hamil mengalami perubahan psikologis berupa kecemasan dan depresi. Sehingga diperlukan upaya pengembangan preventif, promotive dan kuratif sebagai langkah utama dalam memberikan asuhan pada ibu hamil di masa pandemic Covid-19.

Pemberian pendidikan kesehatan berpengaruh terhadap tingkat kecemasan ibu hamil terutama di masa pandemic covid-19 ini, dalam penelitian ini ibu hamil yang telah mendapatkan pendidikan kesehatan mengalami penurunan tingkat kecemasan, hal ini dimungkinkan karena dipengaruhi oleh faktor pendidikan ibu hamil dimana pendidikan sebagian ibu hamil adalah SMA, Pendidikan formal yang dimiliki ibu hamil membatu dan berperan dalam proses penerimaan pendidikan kesehatan yang diberikan oleh peneliti sehingga pendidikan kesehatan mengenai kehamilan dan proses persalinan dimasa pandemic covid-19 ini yang selama ini menjadi kecemasan ibu hamil dapat berkurang walaupun masih ada ibu hamil yang mengalami gangguan psikologis pada point yang sangat rendah sehingga diharapkan baik bidan, keluarga dan suami untuk terus memberikan dukungan kepada ibu hamil sehingga proses kehamilan dan persalinan nantinya dapat berjalan dengan baik. Dengan cara suami terus mendampingi ibu dan memberikan dukungan pada saat ibu melakukan pemeriksaan kehamilan dan mendampingi pada saat proses persalinan beralangsung nantinya.

\section{Pengaruh Pendidikan Kesehatan terhadap Kecemasan Ibu Hamil}

Berdasarkan hasil penelitian dari 36 orang responden diperoleh nilairata-rata tingkat kecemasan sebelum dilakukan pendidikan kesehatan adalah 10,5, dan tingkat kecemasan setelah dilakukan pendidikan kesehatan menurun menjadi 6,6. Nilai signifikansi diperoleh sebesar 0,000 , oleh karena $p=0,000<0,05$ maka dapat dinyatakan 
terdapat pengaruh tingkat kecemasan pada ibu hamil antara sebelum dan setelah dilakukan pendidikan kesehatan. Hasil analisis juga diperoleh $p$ value 0,000 maka dapat dinyatakan terdapat perbedaan tingkat kecemasan sebelum dan setelah pemberian pendidikan kesehatan pada ibu hamil dimasa pandemic covid-19 di Puskesmas Segalamider Kota Bandar Lampung.

Menurut Dale (2019) perubahan psikologis pada ibu hamil lebih komplek dan lebih meningkat terutama pada trimester akhir dibandingkan trimester sebelumnya. Pada masa ini terjadi perubahan emosional dari ibu hamil dimana ibu akan merasakan perasaan gembira bercampur takut karena telah mendekati persalinan. Perubahan ini membuat ibu hamil merasakan kecemasan, khawatir, gelisah dan tidak tenteram. Hampir seluruh ibu hamil mengalami kecemasan yang membedakan adalah tingkat kecemasannya.

Menurut Ernawati dan Hernowo (2016), kecemasan mempunyai efek negatif bagi ibu hamil (khususnya hamil pertama), dengan adanya kecemasan akan meningkatkan kadar katekolamin dalam tubuh ibu. Hal ini dapat menyebabkan penurunan aliran darah ke rahim dan penurunan kontraksi rahim, aliran darah ke plasenta juga menurun sehingga pasokan oksigen ke janin menurun. Masalah ini dapat menjadi ancaman serius bagi keselamatan ibu dan janinnya. Oleh karena itu peneliti berpendapat menghindarkan atau mengurangi stres psikologis pada ibu atau meningkatkan rasa sejahtera bagi ibu akan dapat mendorong proses kehamilan dan persalinan secara fisiologis. Hal ini dapat dilakukan salah satunya dengan pemberian pendidikan kesehatan bagi ibu hamil terutama pada masa pandemic covid-19 saat ini karena kecemasan ibu bukan hanya pada kehamilan dan persalinannya saja tetapi bagaimana pencegahan agar ibu terhindar dari virus covid19 yang saat ini sudah menjadi pandemik.

Hasil penelitian ini juga sejalan dengan penelitian oleh Juneris Aritonang Tahun 2020 tentang Peningkatan Pemahaman Kesehatan pada Ibu hamil dalam Upaya Pencegahan COVID-19. Berdasarkan penelitian yang telah dilakukan diketahui rendahnya pengetahuan ibu hamil menimbulkan rasa cemas atau takut dalam menghadapi kehamilan di era pandemi COVID-19 sehingga dilakukan kegiatan penyuluhan yang dapat meningkatkan pemahaman dan mengurangi kecemasan selama hamil di era pademik dan juga terjadinya perubahan tingkat pengetahuan tentang COVID-19 serta terjadinya penurunan kecemasan sebanyak $12 \%$ setelah dilakukan kegiatan penyuluhan. Pemberian pendidikan kesehatan melalui metode penyuluhan mempengaruhi kecemasan dan kecemasan tidak akan terjadi apabila pengetahuan seseorang tersebut cukup baik.

Berdasarkan hasil penelitian dan teori tersebut diatas, seluruh ibu hamil yang telah dilakukan penilaian tingkat kecemasan diberikan pendidikan kesehatan khususnya bagaimana menghadapi dan mencegah penularan virus covid-19 terutama pada ibu hamil, hasilnya menunjukkan terjadi penurunan tingkat kecemasan pada seluruh ibu hamil walaupun dengan tingkat kecemasan yang berbeda-beda, hal ini disebabkan karena tingkat kecemasan ibu hamil dinilai berdasarkan dari apa yang dialaminya dan pada setiap individu pasti akan berbeda-beda sesuai dengan cara individu menghadapi atau merasakan tingkat kecemasannya. Tetapi secara kuantitatif hasil penelitian ini menunjukkan bahwa pemberian pendidikan kesehatan khususnya cara menghadapi dan melakukan pencegahan terhadap virus covid-19 bagi ibu hamil dapat menurunkan tingkat kecemasan pada seluruh ibu hamil, sebagain besar kecemasan yang dialami oleh ibu hamil adalah gejala somatik atau fisik dan perasaan cemas dengan demikian pendidikan kesehatan dan konseling individual terbukti mampu menurunkan tingkat kecemasan sehingga diharapkan pendidikan kesehatan dapat dijadikan sebagai cara yang digunakan untuk menurunkan tingkat kecemasan pada ibu hamil dalam menghadapi kahamilan dan persalinan yang sehat di masa pandemic covid-19.

Kegiatan ini dapat dilakukan bidan pada kegiatan kelas ibu hamil ataupun kegiatan konsultasi perorangan di Puskesmas yang bertujuan untuk menggali keadaan psikis ibu hamil menghadapi kehamilan dan persalinan di masa pandemic covid-19 ini. Bidan juga dapat membuat media konsultasi secara online sehingga ibu hamil dapat berkonsultasi atau menanyakan permasalahnnya yang berhubungan dengan kehamilan dengan tidak harus bertatap muka dan untuk mencegah terpaparnya ibu hamil pada saat memeriksakan kehamilan tetap mematuhi protokol kesehatan dengan menggunakan masker dan mencuci tangan sebelum dilakukan pemeriksaan serta mebuat temu janji terlebih dahulu untuk menghindari kerumunan pada saat pemeriksaan kehamilan.

\section{KESIMPULAN DAN REKOMENDASI}

Berdasarkan hasil penelitian yang dilakukan dari 36 responden maka peneliti dapat menarik kesimpulan dengan uraian sebagai berikut :

1. Rata-rata tingkat kecemasan ibu hamil pada masa pandemik covid-19 sebelum dilakukan pendidikan kesehatan di Puskesmas Segalamider Kota Bandar Lampung Tahun 2021 sebesar 10,5

2. Rata-rata tingkat kecemasan ibu hamil pada masa pandemik covid-19 setelah dilakukan pendidikan kesehatan di Puskesmas Segalamider Kota Bandar Lampung Tahun 2021 sebesar 6,6

3. Ada pengaruh pemberian pendidikan kesehatan terhadap kecemasan ibu hamil pada masa pandemik covid-19 di Puskesmas Segalamider Kota Bnadar Lampung Tahun 2021 dengan $p$ value $=0,000$.

Diharapkan ibu dapat melakukan konsultasi kepada bidan mengenai keadaan kesehatan fisik dan psikis dengan tetap menerapkan protokol kesehatan sehingga dapat mencegah dari timbulnya kecemasan selama masa kehamilan dan juga ibu hamil dapat membuat grup whatssapp menggunakan gadget yang dikelola oleh petugas sehingga ibu dapat menerima informasi secara langsung, cepat dan tepat jika mengalami kecemasan.

\section{Funding Statement}

The authors did not receive support from any organization for the submitted work and No funding was received to assist with the preparation of this manuscript

\section{Conflict of Interest statement}

Penulis yang namanya tercantum tepat di bawah ini menyatakan bahwa tidak memiliki afiliasi atau keterlibatan dengan pihak luar manapun dan tulisan ini murni dari sumber yang dicantumkan di daftar pustaka serta tidak mengandung plagarisme dari jurnal artikel manapun. Sumber tulisan telah dicantumkan seluruhnya di daftar pustaka. 


\section{REFERENCES}

Arikunto, S (2013). Prosedur Penelitian Suatu Pendekatan Praktek. Jakarta: Rineka Cipta

Aritonang, J., Nugraeny, L., Sumiatik, \& Siregar, R. N. (2020). Peningkatan Pemahaman Kesehatan pada Ibu hamil dalam Upaya Pencegahan COVID-19. Jurnal SOLMA, $9(2)$, 261-269. https://doi.org/10.22236/solma.v9i2.5522

Cameron EE, Joyce KM, Delaquis CP, Reynolds K, Protudjer JLP, Roos LE. (2020). Maternal psychological distress \& mental health service use during the COVID-19 pandemic. Journal of Affective Disorders. 276, (1 November 2020), Pages 765-774. Doi: https://doi.org/10.1016/j.jad.2020.07.081

Dale (2013). Psikologi Kebidanan Memahami Psikis Wanita Seapanjang Daur Hidup Dalam Pelayanan Kebidanan. Yogyakarta: PT. Pustaka Baru

DaudA dkk (2020). Penanganan Corona Virus (Covid-a9) Ditinjau Dari Perspektif Kesehatan Masyarakat. Yogyakarta. Gosyen Publishing

Ernawati, N., \& Hernowo, D. (2016). Pengaruh Pemberian Pendidikan Kesehatan Tentang Proses Persalinan Terhadap Tingkat Kecemasan Ibu Primigravida Trimester III. Jurnal Kesehatan Hesti Wira Sakti,3(2), 45-49. Diambil dari https://jurnal.poltekkessoepraoen.ac.id/index.php/HWS/article/view/110

Hastono (2016). Analisis Data Pada Bidang Kesehatan. Jakarta: PT. Raja Grafindo Persada.

Kemenkes (2020). Pedoman Pencegahan dan Pengendalian Corona Virus Disease (Covid-19). Jakarta. Kementerian Kesehatan RI

Meihartaty dkk (2018). 1000 Hari Pertama Kehidupan. Yogyakarta: Deepublish

Notoatmodjo (2010). Metodologi Penelitian Kesehatan. Jakarta: Rineka Cipta

Notoatmodjo (2018). Promosi Kesehatan Teori dan Apikasi. Jakarta: Rineka Cipta

Pratiwi dan Fatimah (2019). Patologi Kehamilan, Memahami Berbagai Penyakit dan Komplikasi Kehamilan. Yogyakarta: Pustaka Baru

Prawirohardjo (2010). IImu Kebidanan. Jakarta: Yayasan Bina Pustaka Sarwono Prawirohardjo.

Purwaningsih H (2020). Analisis Masalah Psikologis pada Ibu Hamil Selama Masa Pandemi Covid-19 : Literature Review. Call For Paper Seminar Nasional Kebidanan. 2020.

http://jurnal.unw.ac.id/index.php/semnasbidan/article/vi ew/639

Sopiyudin (2015). Statistik Untuk Kedokteran dan Kesehatan: Deskriptif, Bivariat dan Multivariat. Edisi 6 cetakan 2. Jakarta: Epidemiologi Indonesia.
Thapa, S. B., Mainali, A., Schwank, S. E., \& Acharya, G. (2020). Maternal mental health in the time of the COVID-19 pandemic. Acta Obstetricia et Gynecologica Scandinavica. 99(7): 817-818. DOI: https://doi.org/10.1111/aogs.13894

Sutanto dan Fitriana (2019). Asuhan Pada Kehamilan. Yogyakarta: PT. Pustaka Baru

Walyani, ES (2014). Asuhan Kebidanan pada Kehamilan. Yogyakarta. Pustakabarupres

Yuliani D. R., Aini F. N. (2020). Kecemasan Ibu Hamil Dan Ibu Nifas Pada Masa Pandemi Covid-19 di Kecamatan Baturraden. Jurnal Sains Kebidanan, 2(2), 11-14. https://ejournal.poltekkes-

smg.ac.id/ojs/index.php/JSK/article/view/6487

Zamriati, W. O., Hutagaol, E., \& Wowiling, F. (2013). FaktorFaktor yang Berhubungan dengan kecemasan ibu hamil menjelang persalinan di Poli KIA PKM Tuminting. Jurnal Keperawatan, 1(1). Retrieve from https://ejournal.unsrat.ac.id/index.php/jkp/article/view/2 249 